\title{
Study on the Reason, Transformation and Solution Path of Housing Problems
}

\author{
Zhiyong He \\ Huali College Guangdong University of Technology \\ Guangzhou, China 511325
}

\begin{abstract}
The appearance of the housing problem is the supply and demand of housing. Its essence is a complex social problem that is influenced by many factors such as wealth concept, market demand, monetary policy, social governance level and economic growth path. The mismatch of housing property positioning and the excessive opening of the credit system in housing marketization are the fundamental reasons for the "alienation" of housing problems. "Housing financial property - Housing investment demand - Land finance dependence - Housing investment drives economic growth", this closed-loop stimulates housing market price increase expectations, and monetary policy promotes credit expansion (or disguised expansion) in the housing market. The fact that social entities add leverage to housing investment not only exacerbates the systemic financial risks of the housing market, but also brings social moral hazard and social governance risks. Adhering to the positioning of housing property, strengthening the design of housing top-level system, building a hierarchical housing system, implementing housing precision control strategies, promoting the assessment of consequence evaluation, and building a modern economic system are important ways to resolve China's current housing problems.
\end{abstract} path

Keywords-housing problem; alienation; housing property;

\section{INTRODUCTION}

The housing problem has become the focus of concern from different walks of people. The academic community has extensively explored and studied the root causes, essence and countermeasures of housing problems. For example, the root cause of the chaos in the real estate market is the unclear market positioning of housing functions; ${ }^{[1]}$ The root cause of problems in China's housing market lies in one-sided emphasis on the attributes of one aspect, and insufficient understanding of housing social attributes, commodity attributes, investment attributes, etc; [2] China's housing problem stems from the failure to distinguish between the "objective needs" and "market needs" of housing, and the excessive pursuit of "market needs" departing from the "objective need" of housing has led to problems such as overinvestment in housing, financialization of properties, and corporateization of local government behavior; ${ }^{3]}$ We think that the housing problem appears to be an imbalance between the supply and demand of housing. While its essence is a complex systemic effect that is influenced by many factors such as wealth concept, market demand, monetary policy, social governance level, and economic growth path. Returning to the positioning of housing property is the "Archimedes Point" to solve the housing problem. Implementing the route, guideline and policy set by the Party Central Committee on solving the housing problem, that is, insisting that the house is used for live, building the top-level system design of the housing, and comprehensively using financial, fiscal, and legislative means to build a long-term housing mechanism are the fundamental compliance and action guidelines to systematically solve current housing problems in China.

\section{The REASON OF Housing PROBLEM: MARX AND ENGELS' ASSERTION}

When studying the housing problem, Marx pointed out: "Real estate, the original source of all wealth, has become a big problem in modern society. The future of the working class will depend on the solution of this problem." [4] P175 Engels pointed out in the "On Housing Issues" that the housing problem "is not a modern phenomenon." "It is a pain that almost all the oppressed classes of all times have suffered almost equally." To completely solve the housing shortage problem, it needs to be based on the social revolution to "eliminate all exploitation and oppression of the working class by the ruling class", [4] P191 "Residential issues can only be resolved when the society has been fully transformed and may therefore begin to eliminate urban-rural rivalries that have reached a very sharp level in modern capitalist society." [4] P223 That is to say, it is futile and meaningless to think about the solution of housing problem without changing the capitalist mode of production or departing from the reality of the real society. "In modern society, solving this problem is exactly the same as all other social problems, which is solved by the gradual equilibrium of economic supply and demand. After that, the problem will continue to arise, so it is equal to no solution." [4] P205 Marx and Engels pointed out that without changing the unequal status of the proletariat in the entire capitalist relations of production, housing is always in short supply for the proletariat, no matter how the housing supply changes. The "relative surplus" formed by the proletariat's needs of housing and lack of housing purchasing power and the bourgeoisie's pursuit of housing profits is "an inevitable outcome of the bourgeois social form." From Marx and Engels's arguments on housing issues, the housing problem is not a pure commodity supply and demand problem, but a complex social issue involving social production relations, the protection of people's rights and the distribution of labor rights. 


\section{ADVANTAGES AND DisADVANTAGES OF THE MARKETIZATION OF SOCIALIST HOUSING IN THE TRANSFORMATION OF HOUSING PROBLEM}

\section{A. The Reasons and Necessity of the Marketization of Socialist Housing}

After the establishment of China's socialist system, the people became the masters of the country and established a socialist production relationship based on the public ownership of production materials. The leap change of social production relations cannot pass the objective law of insufficient productivity development. The shortage of housing resources caused by the backward productivity of housing construction has always been a major problem that the party and the government need to face. Based on the cognition and productive forces under certain conditions, the Chinese government has fully utilized administrative means to solve the housing problems of urban residents in accordance with the principles of basic fairness and gradual improvement and basically achieved residence. From another point of view, the "first equality, post-rich", near-absolute equality of value orientation, and the "first production, after life", highly centralized planned economic system, have determined the subordination of China's housing construction in the national economy. Limited housing construction investment and housing supply have determined the objective facts of insufficient housing per capita housing for urban residents in China for a long time. With the deepening of reform and opening up and the repositioning and understanding of the relationship between housing commercialization, marketization, housing investment and economic growth, housing marketization has ushered in unprecedented opportunities for development. The "Notice on Further Deepening the Reform of Urban Housing System and Accelerating Housing Construction" the State Council issued in 1998, and the "Notice on Promoting the Healthy Development of the Real Estate Market" in 2003 greatly promoted the sustained and rapid development of the housing market. The support of financial and monetary fiscal policies and the awakening of residents' investment concepts have greatly activated and expanded the housing trading market. The rapid development of real estate investment and housing market has greatly improved the living environment and quality of life of the people and increased the property income of the people while stimulating rapid economic growth and increasing local government fiscal revenue.

\section{B. Housing Alienation in the Marketization of Socialist Housing}

At the same time of the rapid development of the housing market, the alienation phenomenon of "popular economicism" in the housing market has become increasingly apparent. For example, the "real estate speculation" of the whole people has brought about the impact of social values, the impact of ethics ideology, and the government's main economicism greatly damaging the credibility of the government, and the core ideas of housing capitalization challenging the core guiding ideology of social guiding ideology. We believe that the alienation phenomenon in China's housing market is still in the basic vision of Marx and Engels's assertion of housing issues. Its essence is still that housing property is obscured by "capital attributes", and housing gradually evolves into speculative tool of the interests parties to hype and chase high stakes. Under the combined effect of inciting wealth desires and rapid housing price rises, more and more working-class people are forced to get involved in the so-called "capitalization" wave of housing. "In this self-alienation, they feel satisfied and consolidated, and regard this alienation as a powerful proof of their own, and gain the appearance of human existence in this alienation." ${ }^{[5]}$ It is hard to say that this is the luck of the workers. From a longer historical perspective, it is likely to be the misfortune of the workers. After all, once the housing bubble bursts, the "double kill" of property depreciation and repayment pressure will seriously hit the working-class families with high leverage.

\section{The Phenomenon of Housing Alienation Is the Realistic Appearance of "Capital Fetishism" in the "Household Investment" Fanaticism}

The "Investment Characteristics" of housing is just a variant of "capital productivity" and a realistic representation of "capital fetishism" in the contemporary "housing investment" fanaticism. Proudhonists once advocated housing as "the perfect meeting point of family and morality", having housing "is the eternal right to get a certain amount of money each year", and preached the purchase or redemption of rented housing can change the inequality "between the lessee and the lessor" (equal to the relationship between workers and capitalists), while the "law" restrictions on interest rates can achieve eternal fairness of borrowing funds. "Redemption of rented housing... The value of the house is paid back to the original homeowner without much or less... Society... in this way becomes the total of independent free homeowners." [4] ${ }^{\mathrm{P} 201-202}$ The essence of capital appreciation is the possession of means of production and the employment of labor, and the value added in the process of production. Housing is a means of subsistence but does not have the function of producing materials. Advocating housing with the preservation and appreciation of production materials not only masks the essence of capital appreciation, but also opens a new breakthrough for capital to expand into a limited market under the credit system. When the credit system prevails and dominates everything, it moves on to financial capitalism. Millions of dispersed investors have gone through the investment philosophy of being forced to accept, gradual recognition and then eager to follow capital, and finally transfer their savings to the capital-led investment projects. When the debt caused by the crazy expansion of the bank is not enough to cope with it, the government's rescue of financial structure further promotes financial development to a more important position, and financial capital gains control over industry and state. ${ }^{[6] \text { P448 }}$ When the current housing property attribute alienates the financial capital property and floods, even when the local government and financial system have been bundled, the high housing debt will inevitably become the "shackles and chains" that hinder the people's struggle for a better life and development, and become a significant barrier of social development and revolution. 


\section{HOUSING RETURN TO RESIDENTIAL PROPERTIES IS THE RoOT OF THE HEALTHY DEVELOPMENT OF THE HOUSING MARKET}

Giving housing "financial attributes" and thinking about housing from the perspective of housing supply will inevitably fall into the irreconcilable contradiction between limited housing supply and unlimited housing investment demand. Amartya Sen Research pointed out that attempting to estimate the "real shortage" of exchanged goods based on "demand" and "supply" is like finding a black cat that does not exist in a dark house. ${ }^{[7]}$ P103 Returning to the original property of housing, constructing a multi-level housing system that meets the needs of different groups, has become the logical starting point for solving the housing problem.

\section{A. The Return of Housing Property Attributes Is the Need to Enhance the Sense of Security and Access of All People}

Housing is the basic human right that reflects the survival needs of social individuals. It is the basic condition for the protection and realization of the individual's development, creation and communication. It is also the need to maintain and develop family relationships and social production relations. When housing prices rise rapidly, the total assets of the society and the absolute wealth of the owners of the homeowners will grow rapidly. If the income level of the residents has not improved and the social public welfare has not improved, then the residents' ability to "exchange rights" (relative income payment ability) will decline. This is why when the individual's absolute income increases and the relative income does not change, it does not make a significant improvement in the subjective well-being of the individual. Empirical studies have shown that self-owned housing as a fixed asset has no significant impact on the subjective well-being of urban residents. The residential property of the house (the number of rooms, the per capita use of the house, and the time the house has been used) has a significant positive impact on the subjective well-being of the residents. ${ }^{[8]}$ Real estate has a significant positive effect on happiness, but housing liabilities will partially offset the happiness brought about by value added. ${ }^{[9]}$ When most of the residents' income is tied up by the housing, the decline in the ability to "exchange rights" (relative income payment ability) will inevitably affect the subjective well-being of the residents.

\section{B. Promoting the Equalization of Public Services and Returning Housing to Residential Properties Is an Important Indicator of Social Governance and Capacity Improvement}

Education is an intrinsic essence of human beings as a social being. It is a necessary condition for a free, subjective, and social individual to become a self-contained, transcendental, and cultural person. When housing is "embedded" with educational resources (such as housing is linked up with degree) and other social public services - the binding of common attributes of public services with the private ownership of housing rights will inevitably lead to economic rational conflicts, and the housing market is prone to excessive speculation. When the supply of public service resources is constant or decreasing, and the demand for public resources such as degrees is expected to grow, such conflicts will become increasingly fierce. The Chinese people pay special attention to the educational investment of their children. "Don't let the children lose at the starting line" further strengthens the pursuit of quality education resources by Chinese people. The high-priced "school district housing" is a unique product of the combination of public education resources and housing resources due to the simplification of social public management services. The system of embedding social public services into housing attributes for simple management not only strengthens the unfair distribution mechanism of social resources, but also contradicts the modern social governance concept such as the equalization of public services, which is not conducive to the construction of modern state governance system. Promoting the returning of housing property and the steady development of the housing market requires not only the separation of housing and education and other social public resources, but also the promotion of governance functions returning and the improvement of the modernization national government governing capacity.

\section{The Result of the Development of the Housing Market Is That Everyone Has His Home to Live, This Is the Proper Meaning of the Great Socialist Cause of the People's Center}

General Secretary Xi Jinping pointed out that socialism with Chinese characteristics has entered a new era, which is of passionate dreams and opportunities and challenges, and in which everyone has his home to live. To live in own house, as a basic need, is the survival condition of the individual's selfexistence, self-interest and self-transcendence. The United Nations Second Human Habitat Conference "China's Agenda 21: Sustainable Development of Human Habitat" report stated that "the right to adequate housing is a basic human right." [10] The phenomenon of "alienation" of housing has undermined the basic conditions for the survival and development of individuals, and has impeded the value orientation of individual innovation and progress. It can be asserted that a great society cannot be an illusion society that is maintained by an illusory housing "capitalization" bubble. After all, the prosperity under the bubble has a moment of ending. With the Hayek's statement, it is "the greatness of a society is to encourage and protect members of society to explore and innovate their way of life in all possible directions". "11]P12

\section{Path SElEction OF Housing LONG-TERM MECHANISM CONSTRUCTION BASED ON RESIDENTIAL PROPERTY ORIENTATION}

The major conclusions of the party's series of major conferences on the nature of housing issues and the construction of long-term mechanisms have captured the "Archimedes Point" to resolve China's housing problems. The construction of multi-level housing supply system, precise regulation, construction of modern economic system, and paying attention to consequence evaluation are important ways to resolve housing problems. 
A. Building a Multi-level Housing Supply System with the Design of the Top-level Housing System as a Breakthrough

From the current housing market investment frenzy and chaos, the attempt to intervene in the market with the market's spontaneous regulation or simple administrative means is unable to solve the current housing complexity problem.

"Those policies that attempt to establish a completely selfregulating market system, mainly using fictional land, labor, and capital elements as a truth, ignores the fact that these elements represent human beings or are closely related to people's welfare. The implementation of such a policy must mean pain and chaos - unemployment, price volatility, waste, and so on. ${ }^{[12] \text { P118 }}$ Better giving play to the government's better macro-control role in the housing market is the institutional advantage of the socialist countries to do big things, and it is also the key to solving the housing problem. Based on the positioning of housing properties, build a differentiated housing supply system that meets the needs of different levels of housing, namely, commercial housing, affordable housing, shared property housing, and rental housing. Under the guidance of the design of the top-level housing system, actively promote the refinement and implementation of the multi-level housing system, and gradually build a housing dynamic collaborative management and control system with clear rights and responsibilities, standardized management, efficient service, and coordinated order.

\section{B. The System Construction Paying Attention to Consequence Evaluation Ensure That the Government's Regulatory Functions Are Implemented}

Whether the differentiated housing supply system can exert its design effect and put into practice, it requires a standardized and scientific system to restrict the powers and responsibilities and boundaries of the subjects at all levels. The multi-level housing system construction not only involves the coordination and balance of the interests of multiple parties, but also the overall problems of economic development power conversion, economic structure optimization, and systemic risk prevention and control. Due to interest issues, achievements guidance, and lack of ability, some subjects lacked the main motivation and ability in the construction of multi-level housing system and housing longterm mechanism, they took inaction and even chaos. It is necessary to rely on the opportunity to promote the structural reform of the party and state institutions, to guide and standardize the main body of the government at all levels to assume the main responsibility, and to take the major route, guideline and policy already determined by the Party Central Committee as the evaluation indicators of the main departments. It is determined to use the capable ones replacing the average ones, to investigate and call to account the departments and cadres that did the wrong thing. The administrative main subject should focus on the multi-level housing system and the equalization of public services and other targets to build a responsibility implementation mechanism that reflects the corresponding target rights system.

"Rights will directly influence the judgment of action-and only the judgment of action - not the state of affairs that is first embedded, and then influence the evaluation of action by correlating the consequences of action and state."

\section{Implement the Precise Control Strategy of Housing and Strictly Control the Excessive Financialization of the Housing Market}

"As long as there is a clear material need in the country and society, 'the shortage of autocracy' - it still rules people's thoughts and actions, then the distribution of wealth in social production and the conflicts associated with it still occupy the historical front." [13]P16 Under the multi-factor superposition resonance at home and abroad, the housing market bubble has become a potential risk that the Chinese government must focus on prevention. The "capitalization of housing" under high leverage will strengthen the dependence and coupling between housing prices and the financial system and government finance. One-way price consistency will more easily lead to asset price bubbles and increase the risk of dominoes in the bubble burst. To promote the precise regulation of housing, it is necessary to make full use of tools such as big data and real estate registration platforms to accurately calculate the per capita housing area (or number of units) and the total amount of housing credit transactions of households. For speculative real estate speculators, it is necessary to adopt precise measures such as increasing the proportion of house down payment, raising the interest rate on loans, and extending the trading deadline for newly purchased houses. Accelerating the work of real estate tax legislation will help curb the excessive investment demand in the housing market and improve the public's fear of rising housing prices and housing shortages.

\section{Constructing a Modern Economic System and Breaking the Excessive Dependence of Economic Growth on Housing Investment}

Faced with the urgent need for housing alienation and housing system reform, some administrative subjects have many outstanding problems such as lack of leadership ability, weak reform motivation, and low governance level. They are too dependent on the path that land finance and housing investment drive economic growth. The administrative subjects at all levels need to have the wisdom and courage to cure the wounds and carry out self-revolution. The settlement of housing problem must be put at the height of supporting the party's route, guideline and policy and "four consciousnesses", and the height of building a modern economic system, the height of pushing the promotion of the capacity and level of national governance. In this way, it will vigorously improve the government's service capacity and level, create a good business environment, encourage innovation, effectively transform the economic growth mode, improve the quality of economic growth, and break the path dependence of economic growth on housing investment. Vigorously building a healthy, stable and perfect capital market can not only provide strong capital support for promoting scientific and technological innovation and building a modern economic system, but also help divert the huge funds that are concentrated in the housing market, and guide housing investment funds into the real economy. 


\section{CONCLUSION}

The housing problem covers a wide range of areas and has a deep impact. It has become a complex problem in the interest game between the party and the government, residents, enterprises and even the society. Solving the housing problem urgently needs the government and even the market subject and other parties to have the courage to carry out "selfrevolution", resolutely resist the housing investment dependence on "economic terrorism" and the housing investment effect "economic romanticism", around the housing residential property determined to solve the housing problem is the best policy.

\section{REFERENCES}

[1] Yi Xianrong. Research on the Basic System of China's Real Estate Market_Based on the General Analysis of Modern Institutional Economics[J].Jiangsu Social Sciences.2017(5):60-67

[2] Lin Yongmin. Lu Ping, Research on the One-sided Path Reform of Housing Supply Side from the Perspective of Housing Properties[J].Modern Management Science. 2017(8):97-99

[3] Liu Fengyi. Yang Shanqi. Political Economic Analysis of China's Housing Problem [J]. Contemporary Economic Research. 2017(3): 2232

[4] The Works of Marx and Engels Lenins of Central Compilation and Translation Bureau. Selected Works of Marx and Engels. Volume 3 [M] People's Publishing House. 2012.

[5] Marx. The Complete Works of Marx and Engels. Volume 2 [M]. People's Publishing House, 1956.

[6] Commons. Institutional Economics (Volume 2) [M]. Beijing: The Commercial Press. 1962.

[7] Amartya Sen. Poverty and Famine [M]. Beijing: The Commercial Press. 2001.

[8] Zhang Xiang. Li Lunyi. Chai Chengsen. Ma Shuang. Housing Increases Happiness: Is It An Investment Property or A Residential Property? [J]. Financial Research. 2015(10): 17-31

[9] Li Jiangyi. Li Han. Gan Li. Family Assets-Liabilities and Happiness: An Explanation of the Mystery of "Happiness-Revenue" [J], Nankai Economic Research 2015(5): 3-23

[10] The Second United Nations Conference on Human Settlements (Habitat II) China's Agenda 21 - Sustainable Development of Human Habitats [J]. Residential Science and Technology. 1995(8): 9-13

[11] Amartya Sen. Ying Qi Edit. Consequence Evaluation and Practical Rationality [M]. Beijing: Oriental Publishing House. 2006.

[12] Quoted from [United States] Olson. Chen Yu, ect. Translate. The Logic of Collective Action [M]. Gezhi Publishing, et al., 2014.

[13] Ulrich Beck. He Bowen. Risk Society [M]. [Nanjing] Yilin Press. 2004. 